\title{
Combination of ethylene glycol with sucrose increases survival rate after vitrification of somatic tissue of collared peccaries (Pecari tajacu Linnaeus, 1758) ${ }^{1}$
}

\author{
Alana A. Borges ${ }^{2}$, Luiza B. Queiroz Neta², Maria V.O. Santos², Moacir F. Oliveira ${ }^{3}$, \\ Alexandre R. Silva ${ }^{4}$ and Alexsandra F. Pereira ${ }^{2 *}$
}

\begin{abstract}
Borges A.A., Queiroz Neta L.B., Santos M.V.O., Oliveira M.F., Silva A.R. \& Pereira A.F. 2018. Combination of ethylene glycol with sucrose increases survival rate after vitrification of somatic tissue of collared peccary (Pecari tajacu Linnaeus, 1758). Pesquisa Veterinária Brasileira 38(2):350-356. Universidade Federal Rural do Semi-Árido, Universidade Federal Rural do Semi-Árido, BR-110 Km 47, Presidente Costa e Silva, Mossoró, RN 599625-900, Brazil. E-mail: alexsandra.pereira@ufersa.edu.br

The cryopreservation of somatic tissue in collared peccaries promotes an alternative source of genetic material of this specie. The solid-surface vitrification (SSV) is a great option for tissue conservation; nevertheless, the optimization of SSV requirements is necessary, especially when referred to cryoprotectants that will compose the vitrification solution. Therefore, the aim was to evaluate the effect of the presence of $0.25 \mathrm{M}$ sucrose in addition to different combinations (only or association) and concentrations (1.5 M or 3.0 M) of ethylene glycol (EG) and/or dimethyl sulfoxide (DMSO) in the somatic tissue vitrification of collared peccaries. Subsequently, we tested six combinations of cryoprotectants with or without sucrose in Dulbecco modified Eagle medium (DMEM) plus 10\% fetal bovine serum (FBS). Thus, 3.0 M EG with sucrose was able to maintain normal tissue characteristics compared with non-vitrified (control), especially for the volumetric ratio of epidermis (61.2 vs. 58.7\%) and dermis (34.5 vs. 36.6\%), number of fibroblast (90.3 vs. 127.0), argyrophilic nucleolar organizer region (AgNOR) ratio (0.09 vs. 0.17\%) and nucleus area (15.4 vs. $14.5 \mu \mathrm{m}^{2}$ ) respectively. In conclusion, 3.0 M EG with $0.25 \mathrm{M}$ sucrose and 10\% FBS resulted in a better cryoprotectant composition in the SSV for somatic tissue of collared peccaries.

INDEX TERMS: Survival rate, vitrification, somatic tissue, collared peccary, Pecari tajacu, cryobanking, permeable cryoprotectant, non-permeable cryoprotectant, physiology.
\end{abstract}

RESUMO.- [Combinação de etilenoglicol com sacarose aumenta a taxa de sobrevivência após a vitrificação de tecido somático de catetos (Pecari tajacu Linnaeus, 1758).] A criopreservação de tecido somático em catetos promove uma fonte alternativa de material genético nesta espécie. A vitrificação em superfície sólida (VSS) é uma ótima opção para a conservação do tecido; contudo, a otimização dos

\footnotetext{
${ }^{1}$ Received on December 22, 2016. Accepted for publication on June 11, 2017.

${ }^{2}$ Laboratório de Biotecnologia Animal, Universidade Federal Rural do Semi-Árido (UFERSA), BR-110 Km 47, Presidente Costa e Silva, Mossoró, RN 599625-900, Brazil. *Corresponding author: alexsandra.pereira@ufersa.edu.br

${ }^{3}$ Laboratório de Morfofisiologia Aplicada, UFERSA, BR-110 Km 47, Presidente Costa e Silva, Mossoró, RN 599625-900, Brazil.

${ }^{4}$ Laboratório de Conservação de Germoplasma Animal, UFERSA, BR-110 Km 47, Presidente Costa e Silva, Mossoró, RN 599625-900, Brazil.
}

requerimentos da VSS é necessária, especialmente quanto aos crioprotetores que irão compor a solução de vitrificação. Portanto, o objetivo foi avaliar o efeito da presença de $0,25 \mathrm{M}$ de sacarose em adição com diferentes combinações (individual ou associação) e concentrações (1,5 M ou 3,0 M) de etilenoglicol (EG) e/ou dimetilsulfóxido (DMSO) na vitrificação de tecido somático de catetos. Subsequentemente, nós testamos seis combinações de crioprotetores com ou sem sacarose em meio de Eagle modificado por Dulbecco (DMEM) acrescido de $10 \%$ de soro fetal bovino (SFB). Assim, 3,0 M de EG com sacarose foi capaz de manter as características normais do tecido comparado com o não vitrificado (controle), especialmente para a proporção volumétrica da epiderme $(61,2$ vs. 58,7\%) e derme (34,5 vs. 36,6\%), número de fibroblastos $(90,3$ vs. 127,0$)$, razão da região argirófila organizadora de nucléolo (AgNOR) (0,09 vs. 0,17\%) e área 
do núcleo (15,4 vs. 14,5 $\left.\mu \mathrm{m}^{2}\right)$, respectivamente. Em conclusão, 3,0 M de EG com 0,25 M de sacarose e 10\% de SFB resultaram na melhor composição de crioprotetores na VSS para tecido somático de catetos.

TERMOS DE INDEXAÇÃO: Sobrevivência, vitrificação, tecido somático, catetos, Pecari tajacu, criobanco, crioprotetor permeável, crioprotetor não permeável, fisiologia.

\section{INTRODUCTION}

The conservation of somatic tissue of collared peccaries is an alternative tool in the biodiversity maintenance and can be applied in the reproductive biotechnologies, both for the preservation and the breeding management (Machado et al. 2016). The sampling of animals for the cryopreservation is a procedure that can be used for the transportation and storage after collection of the genetic material, maintaining high quality of the tissues and being applied for different purposes (Wong et al. 2012), as the formation of biological resource banks (León-Quinto et al. 2014) and use in somatic cell nuclear transfer (Folch et al. 2009).

In particular, the collared peccary can be used as an experimental model due to phylogenetic proximity to white-lipped peccary (Tayassu peccary Link, 1795) that according to International Union for Conservation of Nature (2016) was listed as vulnerable, having few specimens of this population. Thus, the obtaining of samples of collared peccary, classified as a species least concern and greater accessibility, could be proposed. Additionally, in some situations, the somatic tissue is the only sample of genetic material which possible to collect, to cryopreserve, and notably skin fragments are easy to access (Singh \& Ma 2014).

In general, the cryopreservation is a strategy for genetic conservation of animals, domestic or wild (Benkeddache et al. 2012) and vitrification procedures are superior to conventional cryopreservation by freezing (Brockbank et al. 2010). In the vitrification, the solution is rapidly cooled and transformed into a glassy, vitrified state, not by ice crystallization, but because of extreme elevation in viscosity during cooling (Amorim et al. 2011). The choice of the vitrification is due to the shorter time consumed to perform the technique; it is more economical and easy to be performed in any laboratory (Ting et al. 2013). For optimum conditions, a small volume and high concentration of the vitrification solution that is in contact with the tissue cryopreserved is required. Thus, the solid-surface vitrification (SSV) provides the use of a small amount of a cryoprotectant consisting of direct exposure of the tissue to a pre-cooled solid surface (Carvalho et al. 2011). In previous study, we demonstrated that the SSV was more able to preserve somatic tissue of collared peccary than conventional vitrification using cryovials (Borges et al. 2017b).

Although cell cryopreservation methodologies are applied to tissues, an adaptation of protocols is necessary in order to adjust the requirements of the tissue (Zieger et al. 1996) due to the complexity of many cell types causing water permeability variation in different tissue types (Gandolfi et al. 2006). In collared peccaries, we observed that the peripheral ear integumentary system possessed some important variations compared to other mammals (Borges et al. 2017a) and, therefore, there is the need for development of species-specific protocols of cryopreservation (Agca et al. 2005). The vitrification protocols may improve by varying the composition and concentration of cryoprotectants, which will prevent the rate of formation of ice crystals. Thus, it is necessary to study the effects of different cryoprotectants in somatic tissue of collared peccaries, since the vitrification protocol for somatic tissue of this species is not well established.

Several requirements are specific to different components in the cryopreservation medium; being among these specifications the action mechanism of cryoprotectants that may be intracellular (permeable) or extracellular (non-permeable) (Da-Croce et al. 2013). The permeable cryoprotectants as ethylene glycol (EG) and dimethyl sulfoxide (DMSO) are small molecules that enter the cell and bind with water molecules, limiting the amount of intracellular and extracellular water which protect intracellular organelles (Prentice \& Anzar 2011). Moreover, the permeable cryoprotectants are used in combination with non-permeable cryoprotectants and they are divided in groups: disaccharides (sucrose) and proteins (fetal serum bovine, FBS). These non-permeable cryoprotectants cause cellular dehydration because they do not penetrate the membranes and collaborate for increased osmolality (Sieme et al. 2016). Based on this information, this study aimed to evaluate the effect of the presence of the non-permeable cryoprotectant (sucrose) with different combinations and concentrations of permeable cryoprotectants (EG and/or DMSO) on the somatic tissue vitrification of collared peccaries.

\section{MATERIALS AND METHODS}

The reagents, media, and solutions were obtained from Sigma-Aldrich (St. Louis, MO, USA), Gibco-BRL (Carlsbad, CA, USA), and Labimpex (São Paulo, SP, Brazil).

Animal ethics and care. The study protocol was approved by the Animal Ethics Committee (CEUA/UFERSA; no. 23091.001072/2015-92) and the Chico Mendes Institute for Biodiversity Conservation (ICMBio; no. 48633-2). Eight animals (3-6 months) obtained from the Centre for Wild Animals Multiplication (CEMAS/UFERSA, no. 1478912) were used.

Skin biopsy and experimental design. Initially, in the management of systems of the collared peccaries, their identification is recorded by ear sections and these fragments $\left(1-2 \mathrm{~cm}^{2}\right)$ were recovered for the experiment. Then, skin tissues were transported to the laboratory in Dulbecco modified Eagle medium (DMEM) with $2.2 \mathrm{~g} / \mathrm{L}$ sodium bicarbonate and $2 \%$ antibiotic-antimycotic solution at $37^{\circ} \mathrm{C}$ for $30 \mathrm{~min}$, according to Santos et al. (2016). At the laboratory, the tissue fragments were washed in 70\% ethanol and DMEM. Subsequently, 28 fragments derived from each animal were distributed equally into seven groups among non-vitrified (control) and vitrification solutions, which resulted in four fragments per group of each animal that were divided equally for histological analysis.

The skin tissues were cryopreserved using vitrification solution proposed by Santos et al. (2007), Borges et al. (2009) and Lunardi et al. (2012) with some modifications. Thus, DMEM composed of $2.2 \mathrm{~g} / \mathrm{L}$ sodium bicarbonate and $10 \%$ FBS $\left(\mathrm{DMEM}^{+}\right)$was supplemented with sucrose, EG, and/or DMSO to produce the following six vitrification solutions (VS): EG $\left(\mathrm{DMEM}^{+}+3.0 \mathrm{M} \mathrm{EG}+10 \% \mathrm{FBS}\right), \mathrm{EG}-\mathrm{SUC}\left(\mathrm{DMEM}^{+}+3.0 \mathrm{M} \mathrm{EG}+0.25 \mathrm{M}\right.$ sucrose $+10 \% \mathrm{FBS}$ ), DMSO (DMEM+ $+3.0 \mathrm{M} \mathrm{DMSO}+10 \% \mathrm{FBS})$, DMSO-SUC $\left(\mathrm{DMEM}^{+}+3.0 \mathrm{M}\right.$ DMSO +0.25 M sucrose $+10 \%$ FBS), EG-DMSO (DMEM+ +1.5 M EG +1.5 M DMSO +10\% FBS), and EG-DMSO-SUC $\left(\mathrm{DMEM}^{+}+1.5 \mathrm{M} \mathrm{EG}+1.5 \mathrm{M} \mathrm{DMSO}+0.25 \mathrm{M}\right.$ sucrose $+10 \%$ FBS). After 2 weeks, fragments were warmed and evaluated by integrity analysis, as described in the following. 
Vitrification and warming. Somatic tissues were cryopreserved by SSV according to Borges et al. (2017b) and Carvalho et al. (2011) for collared peccary somatic and caprine ovarian tissues, respectively. Thus, fragments were dissected into dimensions of $9.0 \mathrm{~mm}^{3}$ and randomly allocated for each group. Briefly, four fragments were exposed to $1.8 \mathrm{~mL}$ VS for $5 \mathrm{~min}$, tissues were then dried. Thus, the fragments were individually placed on a cubic metal surface partially in liquid nitrogen $\left(\mathrm{LN}_{2}\right)$ $\left(>10.000^{\circ} \mathrm{C} / \mathrm{min}\right.$ ), transferred to cryovials, and stored in $\mathrm{LN}_{2}$. Posteriorly, the cryovials were maintained for $1 \mathrm{~min}$ at $25^{\circ} \mathrm{C}$ and immersed in a water bath at $37^{\circ} \mathrm{C}$ for $30 \mathrm{sec}$. For removal of cryoprotectants, all fragments were washed three times for $5 \mathrm{~min}$ in $\mathrm{DMEM}^{+}$with sucrose at $0.50 \mathrm{M}, 0.25 \mathrm{M}$, and no sucrose, in order to reduce the osmotic shock.

Morphometric analysis. Samples were fixed in 4\% paraformaldehyde and processed for embedding in paraffin. Sections of 5.0 $\mu \mathrm{m}$ thickness were stained with hematoxylin-eosin and Gomori Trichrome dyes. The histological analysis and morphometry were analyzed using the ImageJ software (US National Institutes of Health, Bethesda, MD, USA) and calculated as the following: the volumetric ratio of the epidermis and dermis, to evaluate if there was any change in tissue size, turgidity or retraction, calculated by: [(number of overlapping structure (dermis or epidermis) to points/total tissue points) $\times 100$ ] (Mota et al. 2014); and quantified the number of fibroblast and perinuclear halos, to analyze if there is decrease of the cellular population and apoptosis, respectively.

AgNOR and quantification. To evaluate the proliferative activity, the histochemical staining of argyrophilic nucleolar organizer region (AgNOR) in the slides was performed in silver solution prepared in 1 part of $2 \%$ gelatin in $1 \%$ aqueous formic acid and 2 parts of $50 \%$ aqueous silver nitrate solution and the slides were exposed in a dark room for $30 \mathrm{~min}$. Subsequently, the slides were washed in $5 \%$ thiosulfate solution for $10 \mathrm{~min}$ (Jaafari-Ashkavandi \& Fatemi 2013). For analyses of each slide (animal/group), AgNOR dots were counted in 100 fibroblasts by Image software in $1000 \times$ magnification. The quantification of AgNOR was performed as: AgNOR area/cell, AgNOR number/cell, nucleus area, and AgNOR ratio (AgNOR area/cell divided by the nucleus area) in accordance to Yang et al. (2013).

Statistical analyses. Data of eight animals were expressed as mean \pm standard error (one animal/one repetition) and analyzed using the GraphPad Prisma 6.0 software (Graph-Pad Software Incorporation; La Jolla, CA, USA) to a significance of $\mathrm{P}<0.05$. All values were verified for normality by the Shapiro-Wilk test and homoscedasticity by Levene's test. Subsequently, when necessary, an arcsine transformation was performed for percentage data. The data of morphometric analysis by volumetric ratio was analyzed by ANOVA (multiple comparisons) followed by Tukey test. Already the results of AgNOR quantification, fibroblast and perinuclear halo numbers were analyzed by Kruskal-Wallis and Dunn (multiple comparisons) tests.

\section{RESULTS}

The morphological features in non-vitrified somatic tissue (control) or after vitrification using six different solutions are shown in Figure 1. For the volumetric ratio of epidermis and dermis (Fig.2), the vitrified fragments in solutions composed of EG without (EG: epidermis: $34.0 \pm 9.2 \%$; dermis: $58.9 \pm 9.3 \%$ ) and with sucrose (EG-SUC: epidermis: $34.5 \pm 9.0 \%$; dermis: $61.2 \pm 9.1 \%$ ) and DMSO without sucrose (DMSO: epidermis: $33.8 \pm 8.7 \%$; dermis: $61.6 \pm 9.2 \%)$ were similar $(\mathrm{P}>0.05)$ to
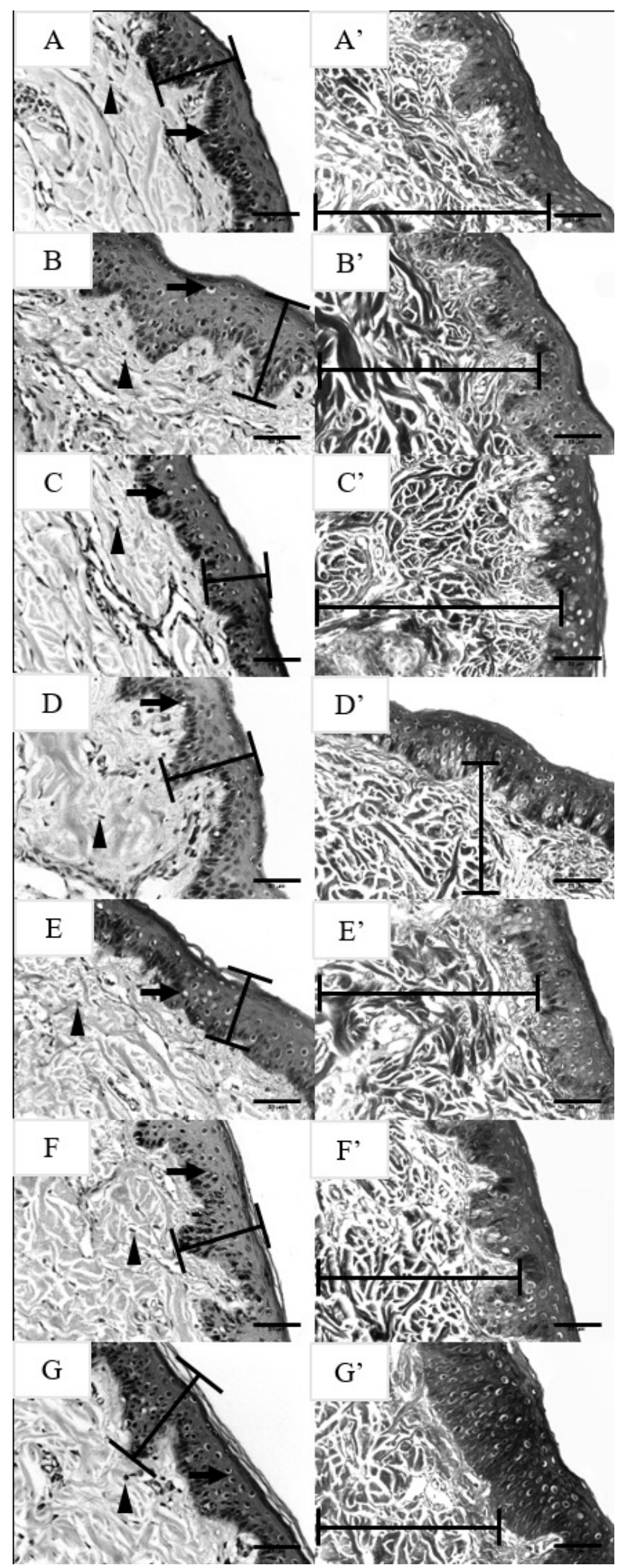

Fig.1. Skin histological sections using hematoxylin-eosin (A-G) and ( $\left.\mathbf{A}^{\prime}-\mathbf{G}^{\prime}\right)$ Gomori's Trichrome, and showing epidermis layers and dermis superficial and deep. Letters indicate, $\mathrm{A}=$ control, $\mathrm{B}=\mathrm{EG}, \mathrm{C}=\mathrm{EG}-\mathrm{SUC}, \mathrm{D}=\mathrm{DMSO}, \mathrm{E}=\mathrm{DMSO}-\mathrm{SUC}, \mathrm{F}=\mathrm{EG}-\mathrm{DMSO}$, and $\mathrm{G}=$ EG-DMSO-SUC. Bars indicate epidermal area in hematoxylin-eosin and dermal area in Gomori's Trichrome; halos (arrow) and (triangle) fibroblast. Scale bars $=50 \mu \mathrm{m}$. 
control (epidermis: $36.6 \pm 10.5 \%$; dermis: $58.7 \pm 10.7 \%$ ) The other groups DMSO with sucrose (DMSO-SUC: epidermis: $32.1 \pm 9.8 \%$; dermis: $62.5 \pm 9.8 \%$ ) and EG-DMSO without (EG-DMSO: epidermis: $33.4 \pm 10.0 \%$; dermis: $62.9 \pm 9.6 \%$ ) and with sucrose (EG-DMSO-SUC: epidermis: $32.7 \pm 9.2 \%$; dermis: $62.3 \pm 8.7 \%)$ differed from the non-vitrified group $(\mathrm{P}<0.05)$.

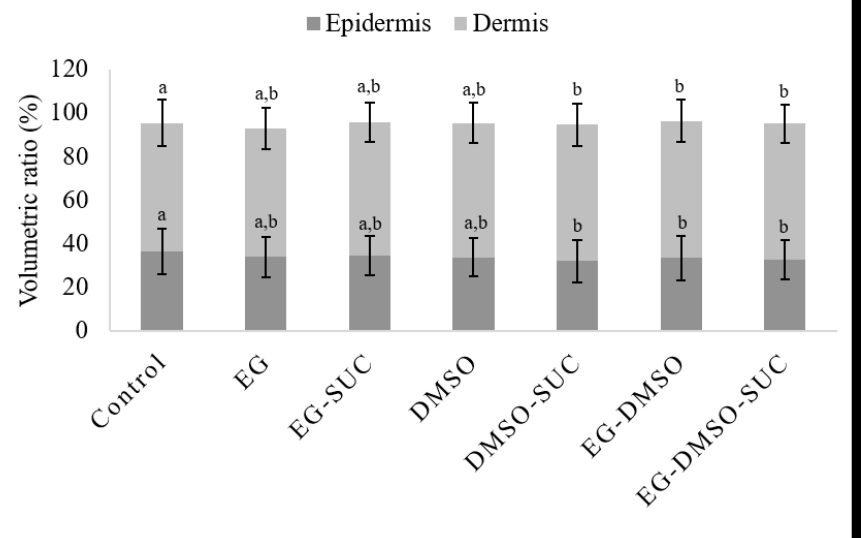

Fig.2. Volumetric ratios of epidermis and dermis at different combination of permeable cryoprotectants and sucrose. Control, EG, EG-SUC, DMSO, DMSO-SUC, EG-DMSO and EG-DMSO-SUC. Bars indicate standard error. a,b Different $(\mathrm{P}<0.05)$ in the same skin layer (epidermis or dermis).
Likewise, none of the vitrified fragments in different solutions were able to maintain the number of fibroblasts similar to non-vitrified fragments (Table 1). Additionally, tissues vitrified in solution composed of EG with and without sucrose, DMSO with sucrose and EG-DMSO without sucrose were those that presented a greater number of fibroblasts. In relation to the number of perinuclear halos (Table 1), vitrified fragments with EG-DMSO-SUC presented least apoptotic characteristics of epidermal cells when compared to other groups $(\mathrm{P}<0.05)$; however, this group did not maintain fibroblast number. On the other hand, the EG-SUC group had a reduced number of perinuclear halos when compared to EG without sucrose (29.3 \pm 3.7 vs. $37.8 \pm 3.7, \mathrm{P}<0.05)$ respectively. Additionally, EG-SUC, DMSO-SUC and EG-DMSO groups showed a good number of fibroblasts and a reduced amount of perinuclear halos.

For the number of AgNOR number/cell, only the vitrified fragments with EG-DMSO-SUC were similar to the control (Table 2). The higher values of the core area were in the groups of combination of cryoprotectants either in the absence or presence of sucrose (EG-DMSO and EG-DMSO-SUC). For AgNOR ratio, only the EG group differed from the control; however, the EG-SUC showed a great result which highlights the benefit of sucrose addition.

In summary, 3.0 M EG with $0.25 \mathrm{M}$ sucrose was able to maintain normal tissue characteristics compared with non-vitrified, especially for the volumetric ratio of epidermis and dermis, number of fibroblast, AgNOR ratio and nucleus area, respectively.

Table 1. Mean number fibroblasts and perinuclear halos of ear skin tissue derived collared peccaries after SSV using different solutions

\begin{tabular}{|c|c|c|c|c|}
\hline \multirow{2}{*}{ Solutions } & \multicolumn{2}{|c|}{ Number of fibroblast } & \multicolumn{2}{|c|}{ Number of perinuclear halos } \\
\hline & Mean \pm S.E. & Range & Mean \pm S.E. & Range \\
\hline Control (non-vitrified) & $127.0 \pm 9.2^{\mathrm{a}}$ & $93-151.5$ & $14.8 \pm 2.2^{\mathrm{a}}$ & $7-21$ \\
\hline EG & $85.7 \pm 5.1^{\mathrm{b}}$ & $59-84$ & $37.8 \pm 3.7^{\mathrm{b}}$ & $24-51$ \\
\hline EG-SUC & $90.3 \pm 5.5^{\mathrm{b}}$ & $72-106$ & $29.3 \pm 3.7^{c}$ & $17-37$ \\
\hline DMSO & $70.9 \pm 3.9^{c}$ & 68-101 & $30.5 \pm 4.1^{\mathrm{c}}$ & $18-40$ \\
\hline DMSO-SUC & $88.2 \pm 5.6^{\mathrm{b}}$ & $69-104$ & $32.3 \pm 4.9^{c}$ & $12-48$ \\
\hline
\end{tabular}

$\overline{\mathrm{a}, \mathrm{b}, \mathrm{c}, \mathrm{d}}$ Different $(\mathrm{P}<0.05)$ in the same column.

Table 2. Comparison of the mean values of argyrophilic nucleolar organizer region (AgNOR) in somatic tissue derived from collared peccary after vitrification with different cryoprotectants

\begin{tabular}{|c|c|c|c|c|}
\hline \multirow{2}{*}{ Solutions } & \multicolumn{4}{|c|}{ Index AgNOR, mean \pm S.E. } \\
\hline & AgNOR area/cell, $\mu \mathrm{m}^{2}$ & AgNOR number/cell & Nucleus area, $\mu \mathrm{m}^{2}$ & AgNOR ratio (\%) \\
\hline Control (non-vitrified) & $1.1 \pm 0.6^{\mathrm{a}, \mathrm{b}}$ & $2.5 \pm 1.0^{\mathrm{a}}$ & $14.5 \pm 6.1^{\mathrm{a}}$ & $0.17 \pm 0.53^{\mathrm{a}}$ \\
\hline EG & $1.0 \pm 0.6^{\mathrm{a}}$ & $1.7 \pm 0.7^{c}$ & $16.8 \pm 8.7^{\mathrm{a}}$ & $0.07 \pm 0.04^{\mathrm{b}}$ \\
\hline EG-SUC & $1.1 \pm 0.9^{\mathrm{a}}$ & $1.6 \pm 0.7^{c}$ & $15.4 \pm 8.7^{\mathrm{a}}$ & $0.09 \pm 0.08^{\mathrm{a}, \mathrm{b}}$ \\
\hline DMSO & $1.1 \pm 0.6^{\mathrm{a}}$ & $1.9 \pm 0.8^{\mathrm{b}}$ & $14.5 \pm 5.5^{\mathrm{a}}$ & $0.08 \pm 0.06^{\mathrm{a}}$ \\
\hline DMSO-SUC & $1.0 \pm 0.7^{\mathrm{a}}$ & $2.0 \pm 0.7^{\mathrm{b}}$ & $15.4 \pm 8.5^{\mathrm{a}}$ & $0.08 \pm 0.05^{\mathrm{a}, \mathrm{b}}$ \\
\hline
\end{tabular}




\section{DISCUSSION}

The results indicated that the best combination of cryoprotectants was $0.25 \mathrm{M}$ sucrose with $3.0 \mathrm{M} \mathrm{EG}$ and $10 \% \mathrm{FBS}$ for the SSV of the somatic tissue derived from collared peccaries. This vitrification solution was more able for most of the evaluated histological parameters. The EG-SUC combination showed an increase in tissue survival when compared the others vitrification solutions with satisfactory results in terms of volumetric ratio of the dermis and epidermis, AgNOR ratio, nucleus area, preserving fibroblasts and presenting a low amount of perinuclear halos. Thus, the association of a permeable cryoprotectant in lower individual concentrations combined with non-permeable agent can facilitate a reduction of the toxicity of a specific individual cryoprotectant (Amorim et al. 2011). Thereby, the SSV in a mixture of sucrose and EG, followed by washes in medium containing sucrose, has the best results also in caprine preantral follicles (Santos et al. 2007), can influence the properties of the solution, and can reduce the toxicity of EG (Orief et al. 2005).

The DMSO and EG are the most commonly used permeable cryoprotectants (Kagawa et al. 2009). For articular cartilage, DMSO and EG were permeable cryoprotectants among the other tested that showed less damage to the sample with the recovery of chondrocytes using reduced doses of 6.0 M DMSO and 7.0 M EG (Fahmy et al. 2014). In previous study, it was verified that the DMSO induced a higher decrease in the number of fibroblasts in swine ovarian tissue, resulting in DMSO being more toxic than EG (Borges et al. 2009), confirming the data from the volume ratio of epidermis and dermis to the EG-SUC (EG and sucrose) has a greater ability to preserve tissue that DMSO-SUC (DMSO and sucrose). Thus, EG is used more in vitrification due to rapid diffusion into cells and low toxicity (Dhali et al. 2000, Orief et al. 2005). It is one of the reasons that may have caused lower damages to the tissue ensuring optimal values of volume ratio in DMSO absence. Additionally, EG has a low molecular weight than DMSO that allows its rapid influx during equilibration and dilution (Bautista \& Kanagawa 1998).

The combination EG, sucrose and FBS improved the vitrification solution for somatic tissue. Corroborating the best result of this work, Lunardi et al. (2012) got best result solid-surface vitrified with $0.25 \mathrm{M}$ sucrose and $10 \% \mathrm{FBS}$ for ovine ovarian tissue. Positive results can be obtained from the addition of sugars in the vitrification solution which has the property to maintain the structural and functional integrity of the membranes in low water activity (Hotamisligil et al. 1996). Moreover, the most efficient method for vitrifying caprine ovarian tissue was the SSV using 0.25 M sucrose and 10\% FBS with EG (Carvalho et al. 2011). Low toxicity is linked to sugars that promote the stable formation of the glassy state at low temperatures, water permeability, and control viscosity increase of the solution and, consequently, require a lower concentration of penetrating cryoprotectants (Bautista \& Kanagawa 1998). In this work, the absence of sucrose with EG (EG) compared to its presence (EG-SUC) has been denoted in proliferative activity by AgNOR ratio that sucrose potentialized the EG. Other work using the vitrification solution containing 40\% EG, 18\% Ficoll, and $0.3 \mathrm{M}$ sucrose demonstrated that vitrification can be applied to cryopreservation of bovine cartilage (Cetinkaya \& Arat 2011). Thus, as predicted by Kuleshova et al. (1999), the properties of the solution must be taken into consideration when one wants to develop a solution for a specific tissue, thus the addition of sugar contributes to the general properties of the solution. Also, they can modify the physical properties of the solution by decreasing the cooling rate (Sutton 1992).

In volume ratio, the EG in combination or not with sucrose was the best preserved tissue in this feature and is more appropriate cryoprotectant that increase the cell permeability and reduce osmotic changes directed to cell volume exposure to cryoprotectants in the cooling or warming (Agca et al. 2005). Thus, the benefit generated by the sucrose was due to cell dehydration caused by osmotic pressure, which provides decrease of intracellular ice (Tanpradit et al. 2015). The mixture of permeable cryoprotectants (EG-DMSO and EG-DMSO-SUC) was less efficient in vitrification solution for preservation of the volumetric ratio of epidermis and dermis. Thus, we can say that for other cellular components as in this study, the combination EG and DMSO showed a high level of toxicity. In this study, we used the concentration of $21.2 \%$ DMSO when used individually and $10.6 \%$ DMSO when applied in combination; these results corroborate Brockbank et al. (2010) that DMSO concentrations of 8-20\% were unsatisfactory in penetrating the cells that do not have the formation of intracellular ice. Silvestre et al. (2003) used rabbit and porcine skin samples, vitrified with solution containing $3.58 \mathrm{M}(20 \%) \mathrm{EG}$ and 2.82 M DMSO in F-PBS, as well as the brown bear skin that used the combination of 20\% FBS, 20\% EG, 20\% DMSO; however suggested that vitrification skin still needs more improvement (Caamaño et al. 2008). For monkey ovarian tissue, the use of $18 \%$ DMSO and EG increased to degrade the damaged cytoplasmic organelles (Hashimoto et al. 2010).

On the other hand, the combination of DMSO with EG showed a high toxicity which has proposed replacements for a combination by the propylene glycol (PG), which is in replacement of the combination of DMSO and EG, both of EG and PG (Nohalez et al. 2015) as DMSO and PG (Somfai et al. 2015) showed less toxic. Additionally, comparing DMSO, EG only, or combination, EG has been used as a permeable cryoprotectant preferably for its control of the cooling rate (Tsuribe et al. 2009).

For AgNOR, it allows to analyze possible changes in the tissue and its ability to ribosome biogenesis indicates in the cells through AgNOR data (Mondal et al. 2015), that was maintained in EG-SUC for AgNOR ratio, but was different for EG. This result, displaying a potentiation of cryoprotectants in the presence of non-permeable cryoprotectants, may be due to the use of permeable cryoprotectants with penetration can cause structural damage to tissue by experimental analysis (Bullen et al.2014). Although no difference was observed for AgNOR area/cell, AgNOR number/cell and nucleus/area, the AgNOR ratio was better for the EG-SUC when compared to the EG group, evidencing the role of sucrose with EG in the somatic tissue conservation.

The successful vitrification combined with extra and intracellular cryoprotectants may be investigated by two mechanisms, by the permeabilization of the cell and to promote intracellular vitrification or at the withdrawal of intracellular water by osmosis before cooling. In murine oocytes and embryos, the main mechanism involved in the vitrification is water removal, on average $85 \%$ of intracellular water allowing to achieve $90 \%$ viability after warming 
(Jin \& Mazur 2015). Thus, it can be combined with sucrose addition which stabilizes the lipid membranes and protein during dehydration of the cells by hydrogen bonding to polar residues in the dry macromolecular (Crowe et al. 1998).

\section{CONCLUSION}

The best result for SSV in somatic tissue of Pecari tajacu was the combination of 3.0 M EG and $0.25 \mathrm{M}$ sucrose with $10 \%$ FBS that allowed the preservation of several characteristics of the tissue after warming, providing the possibility of using this sample for subsequent reproductive biotechnologies, as nuclear transfer.

Acknowledgements.- This study was supported by National Counsel of Technological and Scientific Development (CNPq) and Coordination for the Improvement of Higher Education Personnel (CAPES). The authors thank the Centre for Wild Animals Multiplication (CEMAS/UFERSA) for providing the animals.

\section{REFERENCES}

Agca Y., Mullen S., Liu J., Johnson-Ward J., Gould K., Chan A. \& Critser J. 2005. Osmotic tolerance and membrane permeability characteristics of rhesus monkey (Macaca mulatta) spermatozoa. Cryobiology 51(1):1-14. PMid:15922321. http://dx.doi.org/10.1016/j.cryobiol.2005.04.004.

Amorim C.A., David A., Van Langendonckt A., Dolmans M.M. \& Donnez J. 2011. Vitrification of human ovarian tissue: effect of different solutions and procedures. Fertil. Steril. 95(3):1094-1097. PMid:21168134. http:// dx.doi.org/10.1016/j.fertnstert.2010.11.046.

Bautista J.A.N. \& Kanagawa H. 1998. Current status of vitrification of embryos and oocytes in domestic animals: ethylene glycol as an emerging cryoprotectant of choice. Jpn. J. Vet. Res. 45(4):183-191. PMid:9553322.

Benkeddache D., Bodinier P., Joly T., Berchiche M. \& Vignon X. 2012. Recovery of viable cells from rabbit skin biopsies after storage at $-20^{\circ} \mathrm{C}$ for up to 10 days. Cell Tissue Bank. 13(3):479-486. PMid:22090095. http://dx.doi. org/10.1007/s10561-011-9280-2.

Borges A.A., Bezerra F.V.F., Costa F.N., Queiroz Neta L.B., Santos M.V.O., Oliveira M.F., Silva A.R. \& Pereira A.F. 2017a. Histomorphological characterization of collared peccary (Pecari tajacu Linnaeus, 1758) ear integumentary system. Arq. Bras. Med. Vet. Zootec. 69(4):948-954. http://dx.doi. org/10.1590/1678-4162-9344.

Borges A.A., Lima G.L., Queiroz Neta L.B., Santos M.V.O., Oliveira M.F., Silva A.R. \& Pereira A.F. 2017b. Conservation of somatic tissue derived from collared peccaries (Pecari tajacu Linnaeus, 1758) using direct or solid-surface vitrification techniques. Cytotechnology. 69(4):643-654. PMid:28260212. http://dx.doi.org/10.1007/s10616-017-0074-7.

Borges E.N., Silva R.C., Futino D.O., Rocha-Junior C.M.C., Amorim C.A., Báo S.N. \& Lucci C.M. 2009. Cryopreservation of swine ovarian tissue: effect of different cryoprotectants on the structural preservation of preantral follicle oocytes. Cryobiology. 59(2):195-200. PMid:19616533. http:// dx.doi.org/10.1016/j.cryobiol.2009.07.003.

Brockbank K.G., Chen Z.Z. \& Song Y.C. 2010. Vitrification of porcine articular cartilage. Cryobiology. 60(2):217-221. PMid:20026102. http://dx.doi. org/10.1016/j.cryobiol.2009.12.003.

Bullen A., Taylor R.R., Kachar B., Moores C., Fleck R.A. \& Forge A. 2014. Inner ear tissue preservation by rapid freezing: improving fixation by high-pressure freezing and hybrid methods. Hear. Res. 315:49-60. PMid:25016142. http:// dx.doi.org/10.1016/j.heares.2014.06.006.

Caamaño J.N., Rodriguez A., Salas A., Munoz M., Diez C., Prather R.S. \& Gomez E. 2008. Flow cytometric cell cycle analysis of cultured brown bear fibroblast cells. Cell Biol. Int. 32(7):855-859. PMid:18396424. http:// dx.doi.org/10.1016/j.cellbi.2008.02.005.
Carvalho A.A., Faustino L.R., Silva C.M.G., Castro S.V., Luz H.K.M., Rossetto R., Lopes C.A.P., Campello C.C., Figueiredo J.R., Rodrigues A.P.R. \& Costa A.P.R. 2011. Influence of vitrification techniques and solutions on themorphilogy and survival of preantral follicles after in vitro culture of caprine ovarian tissue. Theriogenology. 76(5):933-941. PMid:21719087. http://dx.doi. org/10.1016/j.theriogenology.2011.04.024.

Cetinkaya G. \& Arat S. 2011. Cryopreservation of cartilage cell and tissue for biobanking. Cryobiology. 63(3):292-297. PMid:22020192. http://dx.doi. org/10.1016/j.cryobiol.2011.09.143.

Crowe J.H., Carpenter J.F. \& Crowe L.M. 1998. The role of vitrification in anhydrobiosis. Annu. Rev. Physiol. 60(1):73-103. PMid:9558455. http:// dx.doi.org/10.1146/annurev.physiol.60.1.73.

Da-Croce L., Gambarini-Paiva G.H.R., Angelo P.C., Bambirra E.A., Cabral A.C.V. \& Godard A.L.B. 2013. Comparison of vitrification and slow cooling for umbilical tissues. Cell Tissue Bank. 14(1):65-76. PMid:22782369. http:// dx.doi.org/10.1007/s10561-012-9301-9.

Dhali A., Manik R.S., Das S.K., Singla S.K. \& Palta P. 2000. Post-vitrification survival and in vitro maturation rate of buffalo (Bubalus bubalis) oocytes: effect of ethylene glycol concentration and exposure time. Anim. Reprod. Sci. 63(3-4):159-165. PMid:10989226. http://dx.doi.org/10.1016/S03784320(00)00170-6.

Fahmy M.D., Almansoori K.A., Laouar L., Prasad V., McGann L.E., Elliott J.A.W. \& Jomha N.M. 2014. Dose-injury relationships for cryoprotective agent injury to human chondrocytes. Cryobiology. 68(1):50-56. PMid:24269869. http://dx.doi.org/10.1016/j.cryobiol.2013.11.006.

Folch J., Cocero M.J., Chesné P., Alabart J.L., Domínguez V., Cognié Y., Roche A., Fernández-Árias A., Martí J.I., Sánchez P., Echegoyen E., Beckers J.F., Bonastre A.S. \& Vignon X. 2009. First birth of an animal from an extinct subspecies (Capra pyrenaica pyrenaica) by cloning. Theriogenology. 71(6):1026-1034. PMid:19167744. http://dx.doi.org/10.1016/j.theriogenology.2008.11.005.

Gandolfi F., Paffoni A., Papassobrambilla E., Bonetti S., Brevini T. \& Ragni G. 2006. Efficiency of equilibrium cooling and vitrification procedures for the cryopreservation of ovarian tissue: comparative analysis between human and animal models. Fertil. Steril. 85(suppl. 1):1150-1156. PMid:16616087. http://dx.doi.org/10.1016/j.fertnstert.2005.08.062.

Hashimoto S., Suzuki N., Yamanaka M., Hosoi Y., Ishizuka B. \& Morimoto Y. 2010. Effects of vitrification solutions and equilibration times on the morphology of cynomolgus ovarian tissues. Reprod. Biomed. Online 21(4):501-509. PMid:20817609. http://dx.doi.org/10.1016/j.rbmo.2010.04.029.

Hotamisligil S., Toner M. \& Powers R.D. 1996. Changes in membrane integrity, cytoskeletal structure, and developmental potential of murine oocytes after vitrification in ethylene glycol. Biol. Reprod. 55(1):161-168. PMid:8793071. http://dx.doi.org/10.1095/biolreprod55.1.161.

International Union for Conservation of Nature 2016. IUCN Red List of Threatened Species. Version 2015.4. Available in <http://www.iucnredlist. org/> Access March, 2016.

Jaafari-Ashkavandi Z. \& Fatemi F.-S. 2013. Evaluation of proliferation activity in and nondysplastic oral lichen planus through the analysis of nucleolar organizer regions. J. Craniofac. Surg. 24(3):788-791. PMid:23714881. http://dx.doi.org/10.1097/SCS.0b013e31828b6e0e.

Jin B. \& Mazur P. 2015. High survival of mouse oocytes/embryos after vitrification without permeating cryoprotectants followed by ultra-rapid warming with an IR laser pulse. Sci. Rep. 5:9271. PMid:25786677.

Kagawa N., Silber S. \& Kuwayama M. 2009. Successful vitrification of bovine and human ovarian tissue. Reprod. Biomed. Online 18(4):568-577. PMid:19401001. http://dx.doi.org/10.1016/S1472-6483(10)60136-8.

Kuleshova L.L., MacFarlane D.R., Trounson A.O. \& Shaw J.M. 1999. Sugars exert a major influence on the vitrification properties of ethylene glycolbased solutions and have low toxicity to embryos and oocytes. Cryobiology. 38(2):119-130. PMid:10191035. http://dx.doi.org/10.1006/cryo.1999.2153. 
León-Quinto T., Simón M.A., Cadenas R., Martínez Á. \& Serna A. 2014. Different cryopreservation requirements in foetal versus adult skin cells from an endangered mammal, the Iberian lynx (Lynx pardinus). Cryobiology. 68(2):227233. PMid:24530371. http://dx.doi.org/10.1016/j.cryobiol.2014.02.001.

Lunardi F.O., Araújo V.R., Faustino L.R., Carvalho A.A., Gonçalves R.F.B., Bass C.S., Báo S.N., Name K.P.O., Campello C.C., Figueiredo J.R. \& Rodrigues A.P.R. 2012. Morphologic, viability and ultrastructural analysis of vitrified sheep preantral follicles enclosed in ovarian tissue. Small Rumin. Res. 107(2-3):121-130. http://dx.doi.org/10.1016/j.smallrumres.2012.04.009.

Machado L.C., Oliveira V.C., Paraventi M.D., Cardoso R.N.R., Martins D.S. \& Ambrósio C.E. 2016. Maintenance of brazilian biodiversity by germplasm bank. Pesq. Vet. Bras. 36(1):62-66. http://dx.doi.org/10.1590/S0100736X2016000100010.

Mondal N.K., Roychoudhury S. \& Ray M.R. 2015. Higher AgNOR expression in metaplastic and dysplastic airway epithelial cells predicts the risk of developing lung cancer in women chronically exposed to biomass smoke. J. Environ. Pathol. Toxicol. Oncol. 34(1):35-51. PMid:25746830. http:// dx.doi.org/10.1615/JEnvironPatholToxicolOncol.2015010708.

Mota C.A., Leão R.A.C., Xavier P.R. \& Marques Júnior A. 2014. Volumetric proportions of placentome structural components of the crossbred HolsteinZebu according to the delivery order. Revta Bras. Reprod. Anim. 38:165-169.

Nohalez A., Martinez C.A., Gil M.A., Almiñana C., Roca J., Martinez E.A. \& Cuello C. 2015. Effects of two combinations of cryoprotectants on the in vitro developmental capacity of vitrified immature porcine oocytes. Theriogenology 84(4):545-552. PMid:25998270. http://dx.doi.org/10.1016/j. theriogenology.2015.04.004.

Orief Y., Schultze-Mosgau A., Dafopoulos K. \& Al-Hasani S. 2005. Vitrification: will it replace the conventional gamete cryopreservation techniques? Middle East Fertil. Soc. J. 10:171-184.

Prentice J.R. \& Anzar M. 2011. Cryopreservation of mammalian oocyte for conservation of animal genetics. Vet. Med. Int. 2011:1-11. (Article ID 146405)

Santos M.L.T., Borges A.A., Queiroz Neta L.B., Santos M.V.O., Oliveira M.F., Silva A.R. \& Pereira A.F. 2016. In vitro culture of somatic cells derived from ear tissue of collared peccary (Pecari tajacu Linnaeus, 1758) in medium with different requirements. Pesq. Vet. Bras. 36(12):1194-1202.http://dx.doi. org/10.1590/s0100-736x2016001200010.

Santos R.R., Tharasanit T., Van Haeften T., Figueiredo J.R., Silva J.R.V. \& Van den Hurk R. 2007. Vitrification of goat preantral follicles enclosed in ovarian tissue by using conventional and solid-surface vitrification methods. Cell Tissue Res. 327(1):167-176. PMid:16937112. http://dx.doi.org/10.1007/ s00441-006-0240-2.

Sieme H., Oldenhof H. \& Wolkers W.F. 2016. Mode of action of cryoprotectants for sperm preservation. Anim. Reprod. Sci. 169:2-5. PMid:26936658. http://dx.doi.org/10.1016/j.anireprosci.2016.02.004.
Silvestre M.A., Saeed A.M., Cervera R.P., Escriba M.J. \& García-Ximénez F. 2003. Rabbit and pig ear skin sample cryobanking: effects of storage time and temperature of the whole ear extirpated immediately after death. Theriogenology. 59(5-6):1469-1477. PMid:12527093. http://dx.doi. org/10.1016/S0093-691X(02)01185-8.

Singh M. \& Ma X. 2014. In vitro culture of fibroblast-like cells from sheep ear skin stored at $25-26^{\circ} \mathrm{C}$ for 10 days after animal death. Int. J. Biol. 6(4):96102. http://dx.doi.org/10.5539/ijb.v6n4p96.

Somfai T., Men N.T., Kaneko H., Noguchi J., Haraguchi S., Nagai T. \& Kikuchi K. 2015. Comparison of sugars, combinations of permeable cryoprotectants, and equilibration regimens for the solid surface vitrification of immature porcine oocytes. Reprod. Fertil. Dev. 27(1):124-124. http://dx.doi. org/10.1071/RDv27n1Ab62.

Sutton R.L. 1992. Critical cooling rates for aqueous cryoprotectants in the presence of sugars and polysaccharides. Cryobiology. 29(5):585-598. PMid:1424715. http://dx.doi.org/10.1016/0011-2240(92)90063-8.

Tanpradit N., Comizzoli P., Srisuwatanasagul S. \& Chatdarong K. 2015. Positive impact of sucrose supplementation during slow freezing of cat ovarian tissues on cellular viability, follicle morphology, and DNA integrity. Theriogenology. 83(9):1553-1561. PMid:25747194. http:// dx.doi.org/10.1016/j.theriogenology.2015.01.035.

Ting A.Y., Yeoman R.R., Campos J.R., Lawson M.S., Mullen S.F., Fahy G.M. \& Zelinski M.B. 2013. Morphological and functional preservation of preantral follicles after vitrification of macaque ovarian tissue in a closed system. Hum. Reprod. 28(5):1267-1279. PMid:23427232. http://dx.doi. org/10.1093/humrep/det032.

Tsuribe P.M., Gobbo C.A.M. \& Landim-Alvarenga F.C. 2009. Viability of primordial follicles derived from cryopreserved ovine ovarian cortex tissue. Fertil. Steril. 91(5, suppl. ):1976-1983. PMid:18555219. http:// dx.doi.org/10.1016/j.fertnstert.2008.03.031.

Wong P.B., Wiley E.O., Johnson W.E., Ryder O.A., O’Brien S.J., Haussler D., Koepfli K.P., Houck M.L., Perelman P., Mastromonaco G., Bentley A.C., Venkatesh B., Zhang Y. \& Murphy R.W. 2012. Tissue sampling methods and standards for vertebrate genomics. Gigascience. 1(1):8. PMid:23587255. http://dx.doi. org/10.1186/2047-217X-1-8.

Yang J.G., Deng Y., Zhou L.X., Li X.Y., Sun P.R. \& Sun N.X. 2013. Overexpression of CDKN1B inhibits fibroblast proliferation in a rabbit model of experimental glaucoma filtration surgery. Invest. Ophthalmol. Vis. Sci. 54(1):343-352. PMid:23233251. http://dx.doi.org/10.1167/iovs.12-10176.

Zieger M.A.J., Tredget E.E. \& McGann L.E. 1996. Mechanisms of cryoinjury and cryoprotection in split-thickness skin. Cryobiology. 33(3):376-389. PMid:8689894. http://dx.doi.org/10.1006/cryo.1996.0038. 